Arab World English Journal (AWEJ) Special Issue on Covid 19 Challenges April 2021

DOI: https://dx.doi.org/10.24093/awej/covid.22

\title{
Challenges and Benefits of Web 2.0-based Learning among International Students of English during the Covid-19 Pandemic in Cyprus
}

\author{
Isyaku Hassan \\ Faculty of Languages and Communication \\ Universiti Sultan Zainal Abidin, Kuala Terengganu, Malaysia \\ Musa BaraU Gamji \\ Department of Mass Communication \\ Ahmadu Bello University, Zaria, Kaduna State, Nigeria \\ Eastern Medtrenian University (EMU), Cyprus \\ Corresponding Author: bmgamji@gmail.com \\ Qaribu Yahaya Nasidi \\ Department of Mass Communication \\ Ahmadu Bello University, Zaria, Kaduna State, Nigeria \\ Mohd Nazri Latiff Azmi \\ Faculty of Languages and Communication \\ Universiti Sultan Zainal Abidin, Kuala Terengganu, Malaysia
}

Received: 2/15/2021

Accepted: 3/2/2021

Published: 4/26/2021

\begin{abstract}
There has been an increased reliance on Web-based learning, particularly in higher learning institutions, due to the outbreak of Covid-19. However, learners require knowledge and skills on how to use Web 2.0based learning tools. Thus, there is a need to focus on how Web-based tools can be used to enhance learning outcomes. Therefore, this study aims to explore the challenges and benefits of Web 2.0-based learning among international students of English as a Second Language (ESL) at the Eastern Mediterranean University (EMU), North Cyprus during the Covid-19 pandemic. The data were collected from a purposive sample of 15 ESL learners at EMU using focus group interviews. The interview data were analyzed using inductive thematic analysis. The findings showed that challenges faced by international students of English at EMU during the Covid-19 pandemic include inadequate knowledge of technology and technical issues such as poor internet connectivity, inability to upload large files, and loss of password. Additionally, the findings showed that Web 2.0 technologies can help the students to enhance collaborative learning, independent learning, flexible learning, as well as competence in using technology for learning purposes. It was envisaged that this study would be beneficial to the management of higher learning institutions, educationists, and students in general. However, this study is limited to international ESL students at EMU with a few participants. To provide generalizable outcomes, further studies may adopt a quantitative or mixed-method approach.

Keyword: Covid-19, Cyprus, ESL learners, international students, learning culture, Web 2.0

Cite as: Hassan, I., Gamji, M. B., Nasidi, Q.Y. \& Azmi, M. N. L. (2021). Challenges and Benefits of Web 2.0-based Learning among International Students of English during the Covid-19 Pandemic in Cyprus.

Arab World English Journal (AWEJ) Special Issue on Covid 19 Challenges (1) 295-306.

DOI: https://dx.doi.org/10.24093/awej/covid.22
\end{abstract}


Arab World English Journal (AWEJ) Special Issue on Covid 19 Challenges April 2021

\section{Introduction}

The emergence of modern communication technology has transformed the way learning activities are conducted (AlJeraisy, Mohammad, Fayyoumi, \& Alrashideh, 2015; MartinezLopez, Yot-Domínguez, \& Trigo, 2020; Meyers, Erickson, \& Small, 2013; Pachler, \& Daly, 2009). Today, learning becomes possible through web 2.0 technologies by utilizing various digital devices to blend the learning system (Abdul Rahman, Azmi, \& Hassan, 2020; AlSamarraie \& Saeed, 2018). These new technologies support learning through Learning Management System (LMS) tools such as student portals, or Content Management Systems (CMS) such as Moodle, MOOCs, Blackboard, and Muse (Al-Samarraie \& Saeed, 2018; Wang, Chen, \& Khan, 2014). However, learners require knowledge and skills on how to use these Web 2.0-based learning support facilities (Hursen, 2020). Students of tertiary institutions struggle to acquire skills and awareness on how to use the new learning system (Rahimi, van den Berg, \& Veen, 2015).

Learning, especially in higher educational institutions, can take place virtually, on a distance space, online and offline via communication technologies, and thus learning becomes a flexible commodity (Collis \& Moonen, 2002; Houlden \& Veletsianos, 2020). The learning environment has witnessed tremendous improvements in the 21 st century with a more complex future (Rahimi et al., 2015). This is because educational scientists continuously attempt to develop and manage more learning tools to support the post-industrial forms of knowledge acquisition around the globe (Warschauer, 2007; Aljawarneh, 2020). These learning tools consist of Learning Management Systems (LMS), such as portals, and Content Management Systems (CMS), such as Blackboard and Moodle (Warschauer, 2007; Abdul Rahman et al., 2020). In essence, communication technology has transformed learning positively by enhancing learning outcomes (Abdullahi, Rouyan, Almetairi, Hassan, 2020; Abdul Rahman et al., 2020).

Due to the outbreak of Covid-19, the educational system has deteriorated remarkably across the globe (Mishra, Gupta, \& Shree, 2020; Hoq, 2020). As such, there has been an increased reliance on Web-based learning, especially in higher learning institutions (Mahyoob, 2020; Martinez, 2020; Hoq, 2020). Thus, there is a need to focus on how Web-based tools can solve this disruption in education and their possible challenges (Hoq, 2020). However, there is inadequate research on challenges faced by students in using Web 2.0 for learning purposes (Rasheed, Kamsin, \& Abdullah, 2020). Also, very few studies focused on challenges faced by international students, particularly learners of English as a Second Language (ESL) in using Web 2.0 for learning among purposes (Prasad, Maag, Redestowicz; Hoe, 2018). Therefore, this study aims to explore the challenges and benefits of Web 2.0-based learning among ESL international students at the Eastern Mediterranean University (EMU), North Cyprus during the Covid-19 pandemic. Specifically, this study aims to address the following research questions.

1. What are the challenges faced by international ESL students in using Web 2.0 tools during the Covid-19 pandemic at the selected institution?

2. How do international ESL students benefit from the use of Web 2.0 tools during the Covid-19 pandemic at the selected institution? 
Arab World English Journal (AWEJ) Special Issue on Covid 19 Challenges April 2021

\section{Literature Review}

\section{Web 2.0 Learning Tools}

Generally, Web 2.0 technologies refer to websites that emphasize user-generated content ease of use, participatory culture, and interoperability for end-users (Bugawa, \& Mirzal, 2018). Web 2.0 tools include Social Networking Sites (SNSs), such as Facebook, WhatsApp, Twitter, Skype, and blogs, and wikis used for discussion and sharing of educational content, as well as synchronized tools that are openly accessible, such as Google Apps and Dropbox (Al-Samarraie \& Saeed, 2018; Wang, Chen, \& Khan, 2014). These accessible resources "have allowed people with common interests to meet, share ideas, and collaborate in innovative ways" (Nedeva \& Dineva, 2012, p. 471).

The implementation of Web 2.0 tools in higher learning institutions promote engagement and interaction among students and thus creates "a more learner-centered learning environment" (Wang, 2010, p. 842). According to Nedeva and Dineva (2012), flexible and collaborative communication tools are used to develop a content-specific platform. Besides, Al-Samarraie and Saeed (2018) noted that Web 2.0 tools "are particularly used to support group members in editing online documents, along with exchanging thoughts and insights related to the subject matter" (p. 6). Thus, instructors are encouraged to inspire their students to employ Web 2.0 tools for formal learning activities and support them to possess online learning competencies (Abdullahi, Rouyan, Noor, \& Bashir, 2018; Bugawa \& Mirzal, 2018; Wang, 2010).

Most of the commonly used LMS have facilities that offer different forms of communication for collaborative knowledge construction (Brown, 2016; Al-Samarraie \& Saeed, 2018). Students could access online materials and track their progress irrespective of where they reside (Wang et al., 2014). Facebook, Twitter, Skype, and WhatsApp were found to be the most commonly used tools for collaborative learning purposes (Al-Samarraie \& Saeed, 2018). Other tools such as multimedia and web platforms were found to be effective in improving teaching and learning experience (Kakosimos, 2015). Specifically, studies found that various tools, such as podcast and videocast, are successfully used to improve students' learning outcomes (PintoLlorente, Sánchez-Gómez, García-Peñalvo, \& Casillas-Martín, 2017; Sarfo \& Yidana, 2016). Various learning tools are combined to support learning activities to face the challenges of today's higher education (Hoic-Bozic, Dlab, \& Mornar, 2015).

\section{Challenges and Benefits of Web 2.0-based Learning}

Several studies have investigated the use of Web-based tools in the learning environment (Hoq, 2020; Mahyoob, 2020; Mishra et al., 2020; Palaigeorgiou \& Grammatikopoulou, 2016; Rasheed et al., 2020). These studies found that the integration of Web 2.0 tools into education has both challenges and benefits. For example, Palaigeorgiou and Grammatikopoulou (2016) identified the challenges and benefits of Web 2.0 learning in traditional learning settings using interviews with teachers. The study found that Web 2.0 learning activities help students learn how to collaborate, create digital content, reflect on their thoughts, extend the time-space of educational dialogue, and promote trust between students and teachers. However, the findings showed that students face various challenges in using Web 2.0 for learning activities, such as the amount of time and effort required, overestimation of students' skills, and lack of training opportunities. 


\section{Arab World English Journal (AWEJ) Special Issue on Covid 19 Challenges April 2021}

Moreover, Rasheed et al. (2020) argued that the integration of technology into education has brought some level of unease to students, instructors, and institutions. For example, students must have "self-regulation skills and technological competence since they are required to manage and carry out their studies independent of their instructor, at their own pace, and also using online technology out of their face-to-face sessions" (p. 2). According to Rasheed et al., challenges faced by students and teachers in using Web 2.0 include inadequate knowledge of technology and self-regulation challenges. Additionally, motivations and background knowledge create great opportunities for students to engage with technologies and develop digital literacy. In this regard, Prasad et al. (2018) measured the extent to which international students develop digital competence. According to the findings, students have significant motivation to engage with unfamiliar technology.

The use of Web 2.0 can be challenging to some international students due to digital culture differences (Ozad \& Barkan, 2004; Vesisenaho, Voltonen, Kukkenen, \& Anu, 2010). Students require skills to use Web 2.0 technologies for learning (Meyers et al., 2007) and they must devote much time to familiarize themselves with the new technology (Prensky, 2003). This is because Web 2.0-based learning is mainly student-centered (Ozad \& Barkan, 2004; HoicBozic et al., 2015). Research shows that the integration of Web 2.0 into the traditional learning approach can help students to develop collaborative learning (Abdul Rahman et al., 2020). As such, digital literacy becomes paramount as the facilities prove effective in developing positive learning outcomes (Eshet-Alkalai, 2004; Hoic-Bozic et al., 2016).

A few studies focused mainly on Web-based learning during the Covid-19 pandemic. For instance, Mishra et al. (2020) examined the use of online teaching-learning during the COVID19 pandemic in India. The study found that the Covid-19 pandemic situation has caused lots of destruction to education and it is challenging to manage online tools for learning, particularly on a long-term basis. Similarly, Hoq (2020) used a survey method to investigate teachers' preference for various e-learning tools during the Covid-19 pandemic in Saudi Arabia. According to the findings, teachers opined that e-learning tools "save time and energy in editing and modernizing of educational materials" (p. 462). However, some teachers do not have the self-confidence to meet the technical demands.

More specifically, Mahyoob (2020) used a survey method to determine the challenges faced by English language learners during the Covid-19 pandemic in Saudi Arabia. The findings showed that learners of English face technical, academic, and communication challenges. According to Mahyoob, "most learners are not satisfied with continuing online learning as they could not fulfill the expected progress in language learning performance" (p. 351). Similarly, Mouchantaf (2020) found that teachers "mainly complained about students missing lectures, technical complications, and a lack of institutional help and training" (p. 1264).

Furthermore, the integration of Web 2.0 facilities in traditional learning components have raised concerns, "but there has been no clear understanding of the challenges that exist in the online component of blended learning" (Rasheed, et al., 2020, p. 1). Ignatow and Robinson (2017) argued that relatively low economic status may also lead to low digital competence. It is uncertain whether the families of international students, particularly from developing countries, can be classified as middle class as understood in Western countries because comparisons are 
complex (Banerjee \& Duflo. 2008). However, there is inadequate research on challenges faced by students in using Web 2.0 for learning purposes (Rasheed et al., 2020). Nevertheless, some studies reported these challenges from teachers' perspectives alone (Brown, 2016; Hoq, 2020). Also, very few studies focused on challenges faced by international students in using Web 2.0 for learning purposes (Prasad et al., 2018).

\section{Methodology \\ Design}

This study employed a qualitative method in which focus group interviews were used to explore the challenges and benefits of Web 2.0-based learning among international ESL students at EMU, Cyprus. According to Jackson (1998), focus group interviews are flexible and relatively easy to conduct. Through focus group interviews, a wide range of themes can be obtained as comments from one participant may generate responses from others (McLafferty, 2004; Jackson, 1998).

\section{Instrument}

This study employed semi-structured interviews with predetermined questions that focus on the challenges and benefits of Web-based learning during the Covid-19 pandemic among international students at EMU, Cyprus. The interview was conducted face-to-face with the participants. Interviews are considered powerful tools for information gathering as participants are allowed to express their views freely on a specific topic (O'Reilly, 2005). The respondents were allowed to freely express their views throughout the interview process. According to Sewell (2008), semi-structured interviews reduce bias when different responses are compared. Also, Creswell (2012) explained that semi-structured interviews generate information that might not be expected by the researchers.

\section{Participants}

The data were collected from a purposive sample of 15 international students of English at EMU, Cyprus. EMU has more than 17,500 students from almost 110 countries around the world (EMU, 2021). Generally, 15 participants are sufficient for focus group interviews (Goss \& Leinbach, 1996). The data collection was performed by a co-author of this study who is part of the students' community. The students were selected based on their willingness to participate in the research.

\section{Procedure of Data Analysis}

The interview data were analyzed using inductive thematic analysis. The analysis was performed using the four stages proposed by Cohen, Manion, and Morrison (2007): Generating natural units of meaning; labeling, categorizing, and ordering the natural units; constructing narratives; and interpretation. Cohen et al. (2007) explained that analysis of qualitative is certainly interpretive, unlike numerical analysis. The coding procedure consists of reading through the interview data, identifying, categorizing, and interpreting themes based on the participants' responses.

\section{Findings}

The purpose of this study was to explore the challenges and benefits of Web 2.0-based learning among international ESL students at EMU during the Covid-19 pandemic. The students 


\section{Arab World English Journal (AWEJ) Special Issue on Covid 19 Challenges April 2021}

were asked to express their feelings regarding the challenges and benefits of Web tools for learning purposes. The participants were 15 international students consisting of 10 males and 5 females from five countries. The first question aims to explore the challenges of using Web 2.0 tools among the students during the Covid-19 pandemic. These challenges are presented in Table 1 based on the students' responses.

Table 1. Challenges of using Web 2.0 technologies

\begin{tabular}{|c|c|c|}
\hline Questions & Themes & Exemplary quotes \\
\hline \multirow[t]{4}{*}{$\begin{array}{l}\text { Based on your experience as } \\
\text { international students, what } \\
\text { challenges do you face in } \\
\text { using Web } 2.0 \text { tools for } \\
\text { learning English? }\end{array}$} & $\begin{array}{l}\text { Inadequate knowledge } \\
\text { of technology }\end{array}$ & $\begin{array}{l}\text {...because I did not use the student } \\
\text { portal in my former school (P4) } \\
\text {...during my secondary school time, } \\
\text { we didn't have a student portal (P1) } \\
\text { I did not use Moodle during my } \\
\text { previous course (P15) }\end{array}$ \\
\hline & $\begin{array}{l}\text { Poor internet } \\
\text { connectivity }\end{array}$ & $\begin{array}{l}\text {...running very slow and I am facing } \\
\text { frequent disruption (11) } \\
\text { Internet connection is often } \\
\text { down...(P2) } \\
\text { I need a proper internet } \\
\text { connection...(P7) } \\
\text {...this is my problem with the lack of } \\
\text { stable internet connection (P5) }\end{array}$ \\
\hline & Large files upload & $\begin{array}{l}\text { It is not easy to upload large } \\
\text { files...(P13) } \\
\text {...as some files exceed maximum size } \\
(\mathrm{P} 11)\end{array}$ \\
\hline & $\begin{array}{l}\text { Loss of login } \\
\text { password }\end{array}$ & $\begin{array}{l}\text { Yes, the challenge I experienced was a } \\
\text { password issue... (P 3) } \\
\text { the password created for you will } \\
\text { suddenly refuse to work...(P14) }\end{array}$ \\
\hline \multirow[t]{2}{*}{$\begin{array}{l}\text { How can these challenges be } \\
\text { addressed? }\end{array}$} & $\begin{array}{l}\text { Training and } \\
\text { orientation }\end{array}$ & $\begin{array}{l}\text { The university should organize } \\
\text { orientation programs...(P1) } \\
\ldots \text { and there should be orientations } \\
(\mathrm{P} 11) \\
\ldots \text { students need to be oriented (P12) } \\
\text { Most of us need to be trained (P14) }\end{array}$ \\
\hline & $\begin{array}{l}\text { Boosting internet } \\
\text { connectivity }\end{array}$ & $\begin{array}{l}\text {...internet connection must be resilient } \\
\text { (P7) } \\
\text { A better internet connection can ease } \\
\text { our tension (P11) } \\
\text {...so we need better WiFi connectivity } \\
\text { (P13) }\end{array}$ \\
\hline
\end{tabular}

Note: $\mathrm{P}=$ Participants

As shown in Table 1, the emerging themes suggest that challenges faced by international ESL students during the Covid-19 pandemic at EMU include inadequate knowledge of technology, poor internet connectivity, inability to upload large files, and loss of password. These findings indicate that some students faced challenges due to insufficient knowledge of using Web-based learning tools and technical factors. The use of Web-based learning tools supports learners' delivery of content. However, to use these technologies, there is a need to develop skills Additionally, the students opined that these challenges can be addressed by 


\section{Arab World English Journal (AWEJ) Special Issue on Covid 19 Challenges April 2021}

providing training and orientation to international students on how to use Web 2.0 technologies more effectively. They also suggested that internet connectivity should be improved.

Moreover, the poor internet connectivity and accessibility cannot be overlooked as the students' online activities are interrupted by low-speed internet. Also, technical competence is of paramount importance because utilization and gaining access to online materials depends largely on an individual's literacy and competence level. Lack of competency with learning tools can be problematic and may obstruct students' progress and possible learning outcomes. The second question aims to identify the benefits of Web 2.0 technologies among international students. This information is depicted in Table 2 as follows.

Table 2. Benefits of using Web 2.0 technologies

\begin{tabular}{|c|c|c|}
\hline \multirow{3}{*}{$\begin{array}{l}\text { Questions } \\
\text { Based on your experience as } \\
\text { international students, what } \\
\text { benefits do you gain by using } \\
\text { Web 2.0 tools for learning } \\
\text { English? }\end{array}$} & Themes & Examplary quotes \\
\hline & Collaborative learning & $\begin{array}{l}\text { It's now easy for me to team up with } \\
\text { my colleagues and connect with } \\
\text { lecturers (P6) } \\
\text { My interactions with colleagues } \\
\text { become easier...(P3) }\end{array}$ \\
\hline & $\begin{array}{l}\text { Independent reading } \\
\text { and writing }\end{array}$ & $\begin{array}{l}\text { I read and write at my pace (P12) } \\
\ldots \text {..now I have enough time to read and } \\
\text { write (P3) } \\
\ldots \text { and makes me feel like a mobile } \\
\text { learner (P14) } \\
\ldots \text { here at EMU, it is flexible (P6) } \\
\text {...because it allows me to present my } \\
\text { work freely (P9) }\end{array}$ \\
\hline \multirow[t]{2}{*}{$\begin{array}{l}\text { What other benefits do you } \\
\text { gain from Web } 2.0 \text { tools in } \\
\text { general? }\end{array}$} & $\begin{array}{c}\text { Access to a variety of } \\
\text { information }\end{array}$ & $\begin{array}{l}\text { It is indeed useful, I love it, it's very } \\
\text { informative... (P14) } \\
\ldots \text { and a lot of things one can access } \\
\text { online (P6) }\end{array}$ \\
\hline & $\begin{array}{l}\text { Competence in using } \\
\text { technology }\end{array}$ & $\begin{array}{l}\text {...so I learn how to use access material } \\
\text { and conduct research (P8) } \\
\ldots \text { and therefore I become more } \\
\text { familiar with new technology (P1) } \\
\text { It helps me develop skills for online } \\
\text { communication (P13) }\end{array}$ \\
\hline
\end{tabular}

Note: $\mathrm{P}=$ Participants

As presented in Table 2, the emerging themes suggest that Web 2.0 technologies can help the students enhance collaborative learning, independent reading and writing, and flexible learning. Additionally, the students believe that Web 2.0 technologies provide a wide range of information for learning purposes. They also believe that Web 2.0 tools help them develop competence in using new communication technology. These findings show that although some students face certain challenges, they still enjoy and benefit from using Web-based learning tools.

According to the findings, Web-based learning creates ample time for students to read and write. Some of the students expressed, "now I have enough time to read and write" (P3), "I read and write at my pace" (P12). They believe that the Web-based learning approach enables them to organize their own pace of study. However, this approach requires support from 
Arab World English Journal (AWEJ) Special Issue on Covid 19 Challenges April 2021

Challenges and Benefits of Web 2.0-based Learning

Hassan, Gamji, Nasidi \& Azmi

instructors and the provision of learning materials for the students. This is because content delivery plays a vital role in supporting online learning experiences.

\section{Discussion of Findings}

The findings of this study showed that, in using Web-based learning tools, international ESL students face challenges related to inadequate knowledge of technology and technical problems such as poor internet connectivity and loss of login passwords. Nevertheless, Web 2.0 technologies benefit the students in terms of collaborative learning, independent and flexible learning, competence in using technology, as well as provision of a wide range of information for learning purposes. These findings concur with some studies on the challenges and benefits of Web-based learning tools (e.g Mahyoob, 2020; Palaigeorgiou \& Grammatikopoulou, 2016; Rasheed et al., 2020). Thus, Web-based learning tools have both challenges and benefits for international ESL students.

According to the findings of this study, some students at EMU face challenges because they did not use Web 2.0 technologies, such as student portal and LMS, in their previous institutions. One of the participants says "during my secondary school time, we didn't have a student portal" (P1). This outcome suggests that prior technical knowledge creates great opportunities for students to engage with technologies and develop digital competence and literacy. Ignatow and Robinson (2017) argued that relatively low economic status may also lead to low digital competence. Additionally, "mastery of digital skills is a precondition for the acquisition of informational advantage" (p. 4). It is uncertain whether the families of international students, particularly from developing countries, can be classified as middle class as understood in Western countries because comparisons are complex (Banerjee \& Duflo. 2008).

Moreover, the traditional learning process is being mediated and blended by Web 2.0 technologies. As a result, learners were termed "digital native" as their brains move toward accommodating the new communication technologies on which they spend most of their time (Prensky, 2003). Students' competencies in using the traditional approach could help them to acquire blended learning skills (Meyers et al., 2013; Warschauer, 2007). Through Web-based learning, students not only require skills but also norms and practices on how to manage learning technologies. As such, students need the competence to learn through the online environment and manipulate digital platforms such as LMS and CMS (Meyers et al., 2013).

The Web-based learning approach involves technical activities for solving learning problems that are student-centered (Hoic-Bozic et al., 2016). Students receive learning materials managed by institutions from their respective faculties, and departments (Ozad \& Barkan, 2004). Thus, institutions partially support course instructors, while learners interact with the instructors. The integration of technologies aims to build stretchy learning atmospheres and develop collaborative learning (Abdul Rahman et al., 2020). This approach could be a challenge, especially to some international students, due to differences in learning culture and background (Vesisenaho et al., 2010).

Even though some international students have prior technical knowledge of Web 2.0 learning tools, there is a need for technological competencies that might influence their use of the facilities at their host institutions. In this regard, Warschauer (2007) argued that to face the 


\section{Arab World English Journal (AWEJ) Special Issue on Covid 19 Challenges April 2021}

current global challenges, institutions must equip learners with e-learning technical skills. This is because digital literacy becomes paramount as the e-learning facilities prove effective in developing positive learning outcomes (Hoic-Bozic et al., 2016). Some of the students suggested that the management of EMU should be organizing orientation programs for new international students on the use of web2.0-based learning facilities, such as student portal and Moodle. A student states "the university should organize orientation programs" (P1). Digital learning aims to help students overcome learning problems and develop their skills (Prensky, 2003).

\section{Conclusion}

This study explored the challenges and benefits of Web 2.0-based learning among international ESL students at EMU during the Covid-19 pandemic. The study revealed that the students face challenges related to technical problems and lack of prior technological competence. However, Web-based learning helps the students to enhance collaborative learning, independent learning, flexible learning, and competence in using Web-based learning tools. These findings indicate that although international students of EMU face challenges, they benefit from using Web-based learning tools.

There is an inadequacy or lack of research into the challenges and benefits of web 2.0based learning among international ESL students, especially during the Covid-19 Pandemic. Therefore, this study advances our understanding of Web-based learning among international ESL students as well as its challenges and benefits during the Covid-19 pandemic. These challenges can be addressed through training and orientation programs on the use of Web 2.0based learning tools, particularly for new students. This objective can be achieved through the collective efforts of educational institutions and relevant authorities. It was envisaged that this study would be beneficial to the management of higher learning institutions, educationists, and students in general. This qualitative research is limited to international ESL students at EMU with a small sample of participants. Therefore, further research may use a mixed-method approach to provide generalizable outcomes.

\section{About the Authors}

Dr. Isyaku Hassan is a Postdoctoral Researcher in the Faculty of Languages and Communication, Universiti Sultan Zainal Abidin (UniSZA), Malaysia. His areas of research interest include media linguistics, media and religion, cultural communication, interactive media, and language studies. https://orcid.org/0000-0002-8260-2894

Musa BaraU Gamji is a lecturer at the Department of Mass Communication, Ahmadu Bello University (ABU), Zaria, Nigeria. His areas of research interest include e-learning, new communication technology, online journalism, and political communication. https://orcid.org/0000-0003-0292-6088

Qaribu Yahaya Nasidi is a lecturer at the Department of Mass Communication, Ahmadu Bello University (ABU), Zaria, Nigeria. His areas of research interest include new media, online journalism, marketing communication, communication research, and media literacy. https://orcid.org/0000-0003-3888-2945 
Arab World English Journal (AWEJ) Special Issue on Covid 19 Challenges April 2021

Dr. Mohd Nazri Latiff Azmi is an Associate Professor of English Language in the Faculty of Languages and Communication, Universiti Sultan Zainal Abidin (UniSZA), Malaysia. His areas of research interest include literacy and comparative literature, language studies, and applied linguistics.https://orcid.org/0000-0002-4712-5332

\section{References}

Abdul Rahman, A. M. A., Azmi, M. N. L., \& Hassan, I. (2020). Improvement of English Writing Skills through Blended Learning among University Students in Malaysia. Universal Journal of Educational Research, 8(12A), 7694-7701.doi: 10.13189/ujer.2020.082556

Abdullahi, A., Rouyan, N. M., Almetairi, M. R., Hassan, I. (2020). Process-oriented writing via computer-mediated peer reviewing: The case of English inner circle learners of Arabic as a Foreign Language. International Journal of Scientific and Technology Research, 9 (4), 3043-3047

Abdullahi, A., Rouyan, N. M., Noor, S. S. M., \& Bashir, I. (2018). The application of Web 2.0 tools to determine receptive skills among Malay learners of the Arabic language at Universiti Sultan Zainul Abidin (UniSZA). E-Academia journal,7(8), 1-7.doi: 10.24191/e-aj.v7iSI-TeMIC18.5379.

Aljawarneh, S. A. (2020). Reviewing and exploring innovative ubiquitous learning tools in higher education. Journal of computing in higher education,32(1), 57-73.doi: 10.1007/s12528-019-09207-0

AlJeraisy, M. N., Mohammad, H., Fayyoumi, A., \& Alrashideh, W. (2015). Web 2.0 in education: The impact of discussion board on student performance and satisfaction. Turkish Online Journal of Educational Technology-TOJET, 14(2), 247-258.

Al-Samarraie, H., \& Saeed, N. (2018). A systematic review of cloud computing tools for collaborative learning: Opportunities and challenges to the blended-learning environment. Computers \& Education, 124(1), 77-91.doi: 10.1016/j.compedu.2018.05.016

Banerjee, A. V., \& Duflo, E. (2008). What is middle class about the middle classes around the world? Journal of economic perspectives, 22(2), 3-28. doi: 10.1257/jep.22.2.3

Brown, M. G. (2016). Blended instructional practice: A review of the empirical literature on instructors' adoption and use of online tools in face-to-face teaching. The Internet and Higher Education, 31(2), 1-10.doi: 10.1016/j.iheduc.2016.05.001

Bugawa, A. M., \& Mirzal, A. (2018). The impact of Web 2.0 technologies on the learning experience of students in higher education: A review. International Journal of Web-Based Learning and Teaching Technologies (IJWLTT), 13(3), 1-17.doi: DOI: 10.4018/IJWLTT.2018070101

Cohen, L., Manion, L., \& Morrison, K. (2007). Research Methods in Education. London and New York: Routledge.

Collis, B., \& Moonen, J. (2002). Flexible learning in a digital world. Open Learning: The Journal of Open, Distance and e-Learning, 17(3), 217-230.doi: 10.1080/0268051022000048228

Creswell, J. W. (2012). Research design: Qualitative, quantitative and mixed-method approaches (2nd ed.). London: SAGE Publications

Eastern Mediterranean University (EMU) (2021). International Students List. Retrieved from: https://www.emu.edu.tr/prospectivestudents

Eshet, Y. (2004). Digital literacy: A conceptual framework for survival skills in the digital era. Journal of Educational Multimedia and Hypermedia, 13(1), 93-106. 
Arab World English Journal (AWEJ) Special Issue on Covid 19 Challenges April 2021

Goss, J. D., \& Leinbach, T. R. (1996). Focus groups as alternative research practice: experience with transmigrants in Indonesia. Area, 28(2), 115-123.

Hoic-Bozic, N., Dlab, M. H., \& Mornar, V. (2015). Recommender system and web 2.0 tools to enhance a blended learning model. IEEE Transactions on Education, 59(1), 39-44. doi: 10.1109/TE.2015.2427116

Hoq, M. Z. (2020). E-Learning during the period of pandemic (COVID-19) in the kingdom of Saudi Arabia: an empirical study. American Journal of Educational Research, 8(7), 457464. doi:10.12691/education-8-7-2

Houlden, S., \& Veletsianos, G. (2020). The problem with flexible learning: Neoliberalism, freedom, and learner subjectivities. Learning, Media and Technology, 18(1), 1-12. 10.1080/17439884.2020.1833920

Hursen, C. (2020). The Effect of Problem-Based Learning Method Supported by Web 2.0 Tools on Academic Achievement and Critical Thinking Skills in Teacher Education. Technology, Knowledge and Learning, 15(1), 1-19.doi: 10.1007/s10758-02009458-2

Ignatow, G., \& Robinson, L. (2017). Pierre Bourdieu: theorizing the digital. Information, Communication \& Society, 20(7), 950-966.doi: 10.1080/1369118X.2017.1301519

Jackson, P. (1998). Focus group interviews as a methodology. Nurse Researcher, 6(1), 72.

Kakosimos, K. E. (2015). Example of a micro-adaptive instruction methodology for the improvement of flipped classrooms and adaptive-learning based on advanced blendedlearning tools. Education for chemical engineers, 12(1), 1-11.doi: /10.1016/j.ece.2015.06.001

Mahyoob, M. (2020). Challenges of e-Learning during the COVID-19 Pandemic Experienced by EFL Learners. Arab World English Journal (AWEJ), 11(4), 51-362. doi:10.24093/awej/vol11no4.23

Martinez, J. (2020). Take this pandemic moment to improve education. EduSource. Retrieved from https://edsource.org/2020/take-this-pandemic-moment-to-improveeducation $/ 633500$.

Martinez-Lopez, R., Yot-Domínguez, C., \& Trigo, M. E. (2020). Analysis of the internet use and students' Web 2.0 digital competence in a Russian university. International Journal of Technology Enhanced Learning, 12(3), 316-342.doi: 10.1504/IJTEL.2020.107986

McLafferty, I. (2004). Focus group interviews as a data collecting strategy. Journal of advanced nursing, 48(2), 187-194. doi: 10.1111/j.1365-2648.2004.03186.x

Meyers, E. M., Erickson, I., \& Small, R. V. (2013). Digital literacy and informal learning environments: an introduction. Learning, media, and technology, 38(4), 355-367.doi: 10.1080/17439884.2013.783597

Mishra, L., Gupta, T., \& Shree, A. (2020). Online teaching-learning in higher education during the lockdown period of the COVID-19 pandemic. International Journal of Educational Research Open, 1(1), 1-8. doi:10.1016/j.ijedro.2020.100012

Mouchantaf, M. (2020). The COVID-19 Pandemic: Challenges Faced and Lessons Learned Regarding Distance Learning in Lebanese Higher Education Institutions. Theory and Practice in Language Studies, 10(10), 1259-1266.doi: 10.17507/tpls.1010.11

Nedeva, V., \& Dineva, S. (2012, November). New learning innovations with Web 4.0. Paper presented at the 7th International Conference on Virtual Learning, Bucharest, Romania.

O'Reilly, K. (2005). Key concepts in ethnography. New York: SAGE Publications. 
Arab World English Journal (AWEJ) Special Issue on Covid 19 Challenges April 2021

Özad, B. E., \& Barkan, M. (2004). Open Learning: Communicating with the Learner. Turkish Online Journal of Educational Technology-TOJET, 3(3), 43-48.

Pachler, N., \& Daly, C. (2009). Narrative and learning with Web 2.0 technologies: towards a research agenda. Journal of Computer Assisted Learning, 25(1), 6-18.doi: 10.1111/j.13652729.2008.00303.x

Palaigeorgiou, G., \& Grammatikopoulou, A. (2016). Benefits, barriers, and prerequisites for Web 2.0 learning activities in the classroom. Interactive Technology and Smart Education 13(1), 2-18.doi: 10.1108/ITSE-09-2015-0028

Pinto-Llorente, A. M., Sánchez-Gómez, M. C., García-Peñalvo, F. J., \& Casillas-Martín, S. (2017). Students' perceptions and attitudes towards asynchronous technological tools in blended-learning training to improve grammatical competence in English as a second language. Computers in Human Behavior, 72(1), 632-643.doi: 10.1016/j.chb.2016.05.071

Prasad, P. W. C., Maag, A., Redestowicz, M., \& Hoe, L. S. (2018). Unfamiliar technology: Reaction of international students to blended learning. Computers \& Education, 122(1), 92-103. 10.1016/j.compedu.2018.03.016

Prensky, M. (2003). Digital game-based learning. Computers in Entertainment (CIE), 1(1), 2122. doi: https://doi.org/10.1145/950566

Rahimi, E., van den Berg, J., \& Veen, W. (2015). Facilitating student-driven constructing of learning environments using Web 2.0 personal learning environments. Computers \& Education, 81(1), 235-246.doi: 10.1016/j.compedu.2014.10.012

Rasheed, R. A., Kamsin, A., \& Abdullah, N. A. (2020). Challenges in the online component of blended learning: A systematic review. Computers \& Education, 144 (1), 103-701.doi: 10.1016/j.compedu.2019.103701

Sarfo, F. K., \& Yidana, I. (2016). University lecturers experience in the design and use of MOODLE and blended learning environments. The Online Journal of New Horizons in Education, 6(2), 143-154.

Vesisenaho, M., Valtonen, T., Kukkonen, J., Havu-Nuutinen, S., Hartikainen, A., \& Karkkainen, S. (2010). Blended learning with everyday technologies to activate students' collaborative learning. Science Education International, 21(4), 272-283.

Wang, M. J. (2010). Online collaboration and offline interaction between students using asynchronous tools in blended learning. Australasian Journal of Educational Technology, 26(6), 830-846. doi: https://doi.org/10.14742/ajet.1045

Wang, M., Chen, Y., \& Khan, M. J. (2014). Mobile cloud learning for higher education: A case study of Moodle in the cloud. International Review of Research in Open and Distributed Learning, 15(2), 254-267. doi: https://doi.org/10.19173/irrodl.v15i2.1676

Warschauer, M. (2007). The paradoxical future of digital learning. Learning Inquiry, 1(1), 41-49. doi 10.1007/s 11519-007-0001-5 